\title{
Pembelajaran Search, Solve, Create and Share (SSCS) untuk Meningkatkan Pemahaman Konsep dan Disposisi Matematis Siswa
}

\author{
Lilis Haniyyah ${ }^{1}$, Khairida Iskandar ${ }^{2}$, Isna Rafianti ${ }^{3 *}$ \\ 1,2,3 Universitas Sultan Ageng Tirtayasa \\ *isnarafianti@untirta.ac.id
}

Diterima: Oktober 2019. Disetujui: Desember 2019. Dipublikasikan: Januari 2020.

\begin{abstract}
ABSTRAK
Penelitian ini dilatarbelakangi oleh rendahnya hasil belajar matematika siswa di Indonesia. Hal ini disebabkan oleh beberapa faktor, diantaranya adalah rendahnya kemampuan pemahaman konsep matematis dan didukung oleh rendahnya disposisi matematis siswa yaitu apresiasi terhadap pembelajaran matematika. Salah satu upaya untuk meningkatkan kemampuan pemahaman konsep matematis dan disposisi matematis siswa adalah dengan menggunakan model pembelajaran Search, Solve, Create and Share (SSCS) yang menjadikan siswa mandiri, aktif dan fokus dalam pembelajaran matematika. Penelitian ini bertujuan untuk mengetahui peningkatan kemampuan pemahaman konsep matematis dan disposisi matematis siswa dengan menggunakan model SSCS dalam pembelajaran matematika. Penelitian ini menggunakan metode quasi eksperimen dengan desain non-equivalent control group design. Subyek penelitian ini adalah kelas VIII C (eksperimen) dan VIII D (kontrol) semester 2 SMPN 2 Kota Serang. Instrumen yang digunakan dalam penelitian ini adalah soal tes kemampuan pemahaman konsep matematis dan skala disposisi matematis. Data hasil penelitian ini dianalisis menggunakan uji normalitas, uji homogenitas, uji perbedaan rata-rata. Kesimpulan dari penelitian ini adalah kemampuan pemahaman konsep matematis siswa yang menggunakan model pembelajaran SSCS lebih baik dari siswa yang menggunakan model pembelajaran konvensional. Disposisi matematis yang menggunakan model pembelajaran SSCS memiliki peningkatan yang lebih rendah atau sama dengan siswa yang menggunakan model pembelajaran konvensional. Dengan demikian model pembelajaran SSCS bisa diterapkan untuk meningkatkan kemampuan pemahaman konsep matematis namun kurang efektif dalam peningkatan disposisi matematis siswa SMP.

Kata kunci: Kemampuan Pemahaman Konsep Matematis, Disposisi Matematis, Model Pembelajaran Search, Solve, Create and Share (SSCS)
\end{abstract}

\begin{abstract}
This research is motivated by the low mathematics learning result of students in Indonesia. This is caused by several factors, such as the low ability of understanding mathematical concepts and supported by the low mathematical disposition of students is the appreciation of mathematics learning. One of the efforts to improve the students' understanding of mathematical concepts and mathematical dispositions is by using Search, Solve, Create and Share (SSCS) learning model which makes students self-reliant, active and focused in learning mathematics. This study aims to determine the improvement of the ability to comprehend mathematical concepts and mathematical disposition of students by using SSCS model in mathematics learning. This research uses quasi experimental method with non-equivalent control group design. The subjects of this research are class VIII C (experiment) and VIII D (control) semester 2 SMPN 2 Serang City. The instrument used in this research is the ability to comprehend mathematical concepts and mathematical disposition scale. Data of this study were analyzed using normality test, homogeneity test, two-party test, and one-party test. The conclusion of this research is the ability of understanding mathematical concepts of students using SSCS learning model better than students using conventional learning model. While mathematical dispositions using SSCS learning models have a lower or equal increase with students using conventional learning models. Thus the SSCS learning model can be applied to improve the comprehension of mathematical concepts but less effective in improving mathematical disposition of Junior High School students.
\end{abstract}

Keywords: Ability to Understand Mathematical Concept, Mathematical Disposition, Search, Solve, Create and Share Learning Model (SSCS).

How to Cite: Haniyyah, L., Iskandar, K., \& Rafianti, I. (2020). Pembelajaran Search, Solve, Create and Share (SSCS) untuk Meningkatkan Pemahaman Konsep dan Disposisi Matematis Siswa. Journal of Medives: Journal of Mathematics Education IKIP Veteran Semarang, 4(1), 97-110. 


\section{PENDAHULUAN}

Pendidikan merupakan sebuah proses pembelajaran yang disengaja untuk menggali kemampuan yang sudah ada dan memperbaiki diri menjadi lebih baik. Secara umum proses pendidikan terjadi dalam 3 lingkungan, yang biasa disebut dengan tripusat pendidikan, yaitu keluarga, sekolah, serta masyarakat. Pendidikan di sekolah bukan hanya bertujuan untuk mengumpulkan pengetahuan semata melainkan juga untuk membentuk sikap dan perbuatan serta menanamkan konsep dan kecekatan atau keterampilan. Salah satu bidang ilmu pengetahuan yang mempunyai peranan penting dalam membentuk sikap dan perbuatan serta menanamkan konsep dan kecekatan atau keterampilan adalah matematika.

Matematika sebagai salah satu mata pelajaran di sekolah yang dinilai cukup memegang peranan penting dalam membentuk siswa menjadi berkualitas, karena matematika merupakan suatu sarana berpikir untuk mengkaji sesuatu secara logis, sistematis dan dipandang mampu mengembangkan potensi siswa secara optimal dalam pendidikan. Hal ini dikarenakan pola pikir matematika itu sangat penting untuk membangun karakter individu di dalam kehidupannya, pada bidang apapun kompetensinya. Menurut Ruseffendi (Anwar, 2013: 1) matematika dipandang sebagai "Queen of Science" atau "ratu ilmu pengetahuan" karena ilmu matematika berguna untuk semua cabang ilmu.

Kilpatrick, Swafford, dan Findell (2001) menyebutkan bahwa dalam pembelajaran matematika ada lima kecakapan matematika (mathematical proficiency) yang seharusnya dapat dicapai oleh siswa adalah pemahaman konsep (conceptual understanding), keterampilan dalam melaksanakan prosedur (procedural fluency), kemampuan untuk merumuskan dan memecahkan masalah matematika (strategic competence), kemampuan untuk berpikir logis (adaptive reasoning) dan memiliki kecenderungan untuk melihat matematika itu masuk akal, berguna, serta bermanfaat (productive disposition). Pada Standar Isi (SI) mata pelajaran matematika untuk semua jenjang pendidikan di sekolah dasar dan menengah menyebutkan bahwa tujuan mata pelajaran matematika adalah agar siswa mampu: (1) memahami konsep matematika, (2) menggunakan penalaran, (3) memecahkan masalah, (4) mengkomunikasikan gagasan, dan (5) memiliki sikap menghargai kegunaan matematika dalam kehidupan (Wardhani, 2008:3).

Sejalan dengan tujuan pembelajaran matematika di atas, pemahaman konsep menjadi salah satu tujuan yang mendasar dalam proses pembelajaran dan salah satu tujuan dari materi yang disampaikan oleh guru. Seperti yang dikatakan Hanim (Rizki, 2015:4) bahwa memahami suatu konsep merupakan hal yang sangat penting bagi siswa dan merupakan tujuan dalam proses pembelajaran, siswa tidak bisa hanya mengerjakan tetapi juga memahaminya. Ini berarti dalam pembelajaran matematika siswa harus memahami konsep matematika terlebih dahulu agar dapat menyelesaikan soal-soal dan mampu mengaplikasikan pembelajaran tersebut di dunia nyata. Konsep-konsep dalam matematika terorganisasikan secara 
sistematis, logis, dan hirarkis dari yang paling sederhana ke yang paling kompleks. Pemahaman terhadap konsepkonsep matematika merupakan dasar untuk belajar matematika secara bermakna. Konsep-konsep merupakan pilar-pilar pembangun untuk berpikir yang lebih tinggi. Dengan mengenal konsep dan struktur yang tercakup dalam pokok bahasan yang sedang dipelajari, peserta didik akan memahami materi yang harus dikuasainya itu. Poin kelima tujuan pembelajaran matematika dalam Standar Isi (SI) mata pelajaran matematika untuk semua jenjang pendidikan sekolah dasar dan menengah, yang termasuk dalam tujuan ranah afektif, yaitu: (a) memiliki sikap menghargai kegunaan matematika dalam kehidupan, yaitu memiliki rasa ingin tahu, perhatian, dan minat dalam mempelajari matematika, serta sikap ulet dan percaya diri dalam pemecahan masalah, Aspek afektif tersebut, dalam dunia matematika lebih dikenal dengan disposisi matematis. Disposisi matematis adalah keinginan, kesadaran, kecenderungan dan dedikasi yang kuat pada diri siswa untuk berpikir dan berbuat secara matematik.

Berdasarkan survei Trends in International Mathematics and Science Study (TIMSS) pada tahun 2011 diketahui bahwa prestasi matematika siswa Indonesia yang diikuti oleh kelas VIII berada pada urutan ke-38 dari 42 negara dengan skor rata-rata 386. Sedangkan survei Programme for International Student Assesment (PISA) pada tahun 2015, menyatakan bahwa prestasi matematika siswa Indonesia berada pada peringkat ke-62 dari 70 negara dengan skor rata-rata 386. Berdasarkan data survei tersebut dapat disimpulkan bahwa prestasi matematika siswa Indonesia masih sangat rendah.

Salah satu model pembelajaran yang paling sering digunakan yaitu model pembelajaran ekspositori. Menurut Sanjaya (2009: 179) model ekspositori adalah pembelajaran yang lebih menekankan pada proses penyampaian materi secara verbal dari seorang guru kepada sekelompok siswa dengan tujuan agar siswa dapat menguasai materi pembelajaran secara optimal. Pembelajaran dengan model ini tidak memberi kesempatan siswa untuk mengeksplorasi materi secara mandiri dan kreatif.

Oleh karena itu, guru perlu menciptakan suasana pembelajaran yang tidak membosankan untuk siswa. Banyak model pembelajaran yang sudah ada, salah satunya adalah model pembelajaran SSCS. Pembelajaran bermodel seperti ini biasanya memudahkan siswa dalam menyelesaikan soal-soal matematika yang diberikan oleh guru. Model pembelajaran SSCS ini memiliki ciri khas dimana proses pembelajarannya meliputi empat fase, yaitu: fase search yang bertujuan untuk mengidentifikasi masalah. Pada fase ini siswa diharuskan memahami permasalahannya dan juga mencakup indikator kemampuan pemahaman konsep yaitu dapat menyatakan ulang sebuah konsep, mengklasifikasikan objek menurut sifat-sifat tertentu sesuai dengan konsepnya dan memberikan contoh atau bukan contoh dari sutau konsep karena siswa dituntut untuk mencari informasi yang diperlukan. Sedangkan indikator disposisi yang tercakup dalam fase ini adalah ketertarikan terhadap matematika dan 
metakognisi. Selanjutnya, fase solve yang bertujuan untuk merencanakan penyelesaian masalah. Dalam fase ini ada beberapa indikator pemahaman konsep yang tercakup, yaitu menyajikan konsep dalam berbagai bentuk representatif matematis dan mengembangkan syarat perlu atau syarat cukup dari suatu konsep, karena siswa harus menentukan ide penyelesaian dari permasalahan yang ada. Sedangkan indikator disposisi yang tercakup dalam fase ini adalah kegigihan dan ketekunan. Kemudian fase create yang bertujuan untuk melaksanakan penyelesaian masalah, dalam fase ini indikator pemahaman konsep yang dapat dicapai adalah menggunakan dan memanfaatkan serta memilih prosedur atau operasi tertentu serta mengaplikasikan konsep atau algoritma dalam pemecahan masalah. Sedangkan indikator disposisi yang tercakup dalam fase ini adalah fleksibelitas. Dan yang terakhir fase share yang bertujuan untuk mensosialisasikan penyelesaian masalah yang dilakukan. Dalam fase ini disposisi matematis siswa akan terlihat yaitu kepercayaan diri, fleksibelitas, dan metakognisi. Melalui fase-fase SSCS ini, diharapkan dapat membantu siswa dalam membentuk sebuah konsep matematis yang tepat sehingga siswa dapat memecahkan masalah baik secara berkelompok maupun secara individu serta meningkatkan disposisi matematis siswa dalam menyelesaikan masalahmasalah matematika.

Rumusan masalah pada penelitian ini adalah sebagai berikut. (1) Apakah peningkatan kemampuan pemahaman konsep matematis siswa yang belajar matematika menggunakan SSCS lebih baik daripada siswa yang belajar matematika secara konvensional? (2) Apakah peningkatan disposisi matematis siswa yang belajar matematika menggunakan model SSCS lebih baik daripada siswa yang belajar matematika secara konvensional?

Menurut Sanjaya (Harja, 2012) yang dimaksud pemahaman konsep adalah kemampuan siswa yang berupa penguasaan sejumlah materi pelajaran, dimana siswa tidak sekedar mengetahui atau mengingat sejumlah konsep yang dipelajari, tetapi mampu mengungkapan kembali dalam bentuk lain yang mudah dimengerti, memberikan interprestasi data dan mampu mengaplikasikan konsep yang sesuai dengan struktur kognitif yang dimilikinya. Indikator pemahaman konsep matematis dalam penelitian ini mengacu pada Peraturan Dirjen Dikdasmen Nomor 506/C/Kep/PP/2004 tanggal 11 November 2001 tentang rapor, yang isinya adalah siswa mampu: (1) menyatakan ulang sebuah konsep, (2) mengklasifikasikan objek menurut sifat-sifat tertentu sesuai dengan konsepnya, (3) memberikan contoh dan bukan contoh dari suatu konsep, (4) menyajikan konsep dalam berbagai bentuk representasi matematis, (5) mengembangkan syarat perlu atau syarat cukup dari suatu konsep, (6) menggunakan dan memanfaatkan serta memilih prosedur atau operasi tertentu, (7) mengaplikasikan konsep atau algoritma dalam pemecahan masalah.

Menurut Hiebert dan Carpenter (Harja, 2012) pengajaran yang menekankan kepada pemahaman mempunyai sedikitnya 5 keuntungan. Keuntungan- 
keuntungan tersebut adalah sebagai berikut. (1) Pemahaman memberikan generatif artinya seorang telah memahami suatu konsep, maka pengetahuan itu akan mengakibatkan pemahaman karena adanya jalinan antar pengetahuan yang dimiliki siswa sehingga setiap pengetahuan baru melalui keterkaitan dengan pengetahuan yang sudah ada sebelumnya. (2) Pemahaman memacu ingatan artinya suatu pengetahuan yang telah dipahami dengan baik akan diatur dan dihubungkan secara efektif dengan pengetahuan yang lain melalui pengorganisasian skema atau pengetahuan secara lebih efisien didalam struktur kognitif sehingga pengetahuan itu lebih mudah diingat. (3) Pemahaman mengurangi banyaknya hal yang harus diingat artinya jalinan terbentuk antara pengetahuan yang satu dengan yang lain dalam struktur kognitif siswa yang mempelajarinya dengan penuh pemahaman merupakan jalinan yang sangat baik. (4) Pemahaman meningkatkan transfer belajar artinya pemahaman suatu konsep matematika akan diperoleh siswa yang aktif menemukan keserupaan dari berbagai konsep tersebut. Hal ini akan membantu siswa untuk menganalisis apakah suatu konsep tertentu dapat diterapkan untuk suatu kondisi tertentu. (5) Pemahaman mempengaruhi keyakinan siswa artinya siswa yang memahami matematika dengan baik akan mempunyai keyakinan yang positif yang selanjutnya akan membantu perkembangan pengetahuan matematikanya.

NCTM (1999) menyatakan, tujuan pembelajaran matematika adalah mengembangkan: kemampuan mengeksplorasi, menyusun konjektur dan menyusun alasan secara logis; kemampuan menyelesaikan masalah non rutin; kemampuan berkomunikasi secara matematis dan menggunakan matematika sebagai alat komunikasi, kemampuan menghubungkan antar ide matematika dan antar matematika dan aktivitas intelektual lainnya (Marogi, 2016). Tujuan tersebut menggambarkan bahwa pembelajaran matematika tidak hanya dimaksudkan untuk mengembangkan kemampuan kognitif matematis, melainkan juga aspek afektif, seperti disposisi matematika. Dalam konteks matematika, NCTM (1989) menyatakan disposisi matematis adalah keterkaitan dan apresiasi terhadap matematika yaitu suatu kecenderungan untuk berpikir dan bertindak dengan cara yang positif (Trisniawati, 2013). Disposisi matematis penting untuk dikembangkan karena dapat menunjang keberhasilan siswa dalam belajar matematika. Dengan menggunakan disposisi matematis yang dimiliki oleh siswa, diharapkan siswa dapat menyelesaikan masalah, mengembangkan kegiatan kerja yang baik dalam matematika, serta bertanggung jawab terhadap belajar matematika. Indikator disposisi matematis yang akan ditingkatkan dalam penelitian ini adalah ketertarikan terhadap matematika, kepercayaan diri siswa, kegigihan dan ketekunan, fleksibelitas, dan metakognisi.

Untuk meningkatkan serta mencapai indikator kemampuan pemahaman konsep matematis dan disposisi matematis, peneliti menggunakan model SSCS dalam pembelajaran matematika. SSCS adalah model pembelajaran yang memakai pendekatan problem solving, didesain untuk mengembangkan kete- 
rampilan berpikir kritis dan meningkatkan pemahaman terhadap konsep ilmu. Model pembelajaran SSCS ini dikemukakan oleh Edward L Pizzini seorang ahli pendidikan dari pusat pendidikan ilmu pengetahuan dari Universitas IOWA pada tahun 1988 pada mata pelajaran sains (IPA) (Deli, 2015:72). Selanjutnya Pizzini, Abel dan Shepardson (1988) serta Pizzini dan Shepardson (1990) menyempurnakan model ini dan mengatakan bahwa model ini tidak hanya berlaku untuk pendidikan sains saja, tetapi juga cocok untuk pendidikan matematika (Irwan, 2011:2).

Teori yang mendasari model pembelajaran SSCS adalah teori konstruktivisme Piaget yang menjelaskan bahwa proses dibangunnya sebuah pengetahuan dari stimulus baru dilakukan dengan dua cara, yaitu asimilasi dan akomodasi. Asimilasi adalah proses pengintegrasian informasi baru ke dalam struktur pikiran. Sedangkan akomodasi adalah proses membentuk atau memodifikasi struktur pikiran karena adanya informasi baru yang tidak dapat diasimilasi. Dengan demikian dalam proses asimilasi, seseorang hanya memperoleh pengetahuan baru tetapi tidak menambahkan kualitas pengetahuan, sedangkan pada proses akomodasi kualitas pengetahuan seseorang akan bertambah (Suherman, 2003:36). Dan didukung oleh teori Vygotsky yaitu scaffolding dimana scaffolding berarti memberikan kepada seorang anak sejumlah besar bantuan selama tahaptahap awal pembelajaran dan kemudian mengurangi bantuan tersebut dan memberikan kesempatan kepada anak tersebut mengambil alih tanggung jawab yang semakin besar segera setelah mampu mengerjakan sendiri. Bantuan yang diberikan guru dapat berupa petunjuk, peringatan, dorongan, menguraikan masalah ke dalam bentuk lain yang memungkinkan siswa dapat mandiri. Sejalan dengan prinsip dan pendapat tersebut maka terlihat bahwa model pembelajaran SSCS berorientasi pada teori pembelajaran konstruktivisme.

\section{METODE PENELITIAN}

Metode yang digunakan dalam penelitian ini adalah metode kuasi eksperimen. Variabel bebas yang diberikan pada penelitian ini adalah model pembelajaran SSCS. Sedangkan variabel terikatnya adalah kemampuan pemahaman konsep matematis dan disposisi matematis siswa. Desain penelitian ini adalah non-equivalent control group design yang digambarkan sebagai berikut.

$$
\begin{array}{cccc}
\mathrm{O} & \mathrm{X} & \mathrm{O} & (\text { Eksperimen) } \\
\ldots \ldots \ldots \ldots \ldots \ldots \ldots \ldots . . . & \\
\mathrm{O} & \mathrm{O} & \begin{array}{c}
\text { (Kontrol) } \\
\text { (Ruseffendi, 2010: 53) }
\end{array}
\end{array}
$$

Populasi dalam penelitian ini adalah seluruh kelas VIII di SMP Negeri 2 Kota Serang. Sampel dipilih dengan menggunakan teknik accidental sampling yaitu sampel diambil secara sengaja, tanpa direncanakan terlebih dahulu. Peneliti menggunakan teknik ini karena sampel yang peneliti ambil merupakan sampel yang ditentukan oleh pihak sekolah karena ketersediaan di sekolah. Ada dua kelas yang dijadikan sampel. Kelas eksperimen adalah kelas VIII C dan kelas kontrol adalah kelas 
VIII D. Data yang digunakan pada penelitian ini adalah hasil pretest, posttest, dan $\mathrm{N}$-gain untuk kemampuan pemahaman konsep matematis, sedangkan untuk disposisi matematis peneliti mengambil data dari skala awal, skala akhir, dan $N$-gain. Data tersebut diperoleh dari 80 siswa, yang terdiri dari 40 siswa kelas eksperimen dan 40 siswa pada kelas kontrol.

Instrumen yang digunakan pada penelitian ini yaitu soal tes kemampuan pemahaman konsep matematis dan skala disposisi matematis. Sebelum instrumen digunakan, terlebih dahulu melakukan uji validitas teoritik dan empirik. Selanjutnya setelah data pretest dan posttest kemampuan pemahaman konsep matematis serta skala awal dan skala akhir disposisi matematis siswa didapat maka dilakukan analisis data dengan menggunakan uji t. Sebelum dianalisis diuji terlebih dahulu dengan uji prasyarat yaitu uji normalitas dan homogenitas untuk setiap data pretest, posttest, dan $N$ gain, baik kemampuan pemahaman konsep maupun disposisi matematis.

HASIL DAN PEMBAHASAN Kemampuan Pemahaman Konsep
Matematis

Untuk kemampuan pemahaman konsep matematis, peneliti menggunakan data hasil penelitian yang berupa data pretest, posttest, dan $N$-gain. Tabel 1 menyajikan statistik deskriptif untuk data nilai pretest, posttest, dan $N$-gain.

Dari Tabel 1, dapat dilihat bahwa untuk rata-rata nilai pretest kelas eksperimen lebih tinggi dibandingkan dengan kelas kontrol. Selanjutnya dilakukan uji normalitas untuk melihat
Tabel 1. Statistika Deskriptif Data Nilai

Pretes, Postes dan N-gain Kemampuan Pemahaman Konsep Matematis

\begin{tabular}{|c|c|c|c|c|c|c|}
\hline \multirow{2}{*}{ Kategori } & \multicolumn{2}{|c|}{ Pretes } & \multicolumn{2}{|c|}{ Postes } & \multicolumn{2}{|c|}{$\mathrm{N}$-gain } \\
\hline & Eks & Kon & Eks & Kon & Eks & Kon \\
\hline $\begin{array}{l}\text { Banyak } \\
\text { siswa }\end{array}$ & 40 & 40 & 40 & 40 & 40 & 40 \\
\hline $\begin{array}{l}\text { Data } \\
\text { terbesar }\end{array}$ & 50 & 55 & 97 & 93 & 0,95 & 0,85 \\
\hline $\begin{array}{l}\text { Data } \\
\text { terkecil }\end{array}$ & 7 & 7 & 30 & 22 & 0,12 & 0,13 \\
\hline $\mathrm{R}$ & 43 & 48 & 67 & 71 & 0,83 & 0,72 \\
\hline Rata-rata & 33,10 & 27,85 & 70,25 & 54,77 & 0,57 & 0,42 \\
\hline $\begin{array}{l}\text { Simpangan } \\
\text { baku }\end{array}$ & 11,77 & 12,87 & 39,35 & 16,89 & 0,23 & 0,20 \\
\hline Varians & 138,70 & 165,72 & 394,2 & 285,35 & 0,05 & 0,04 \\
\hline
\end{tabular}

apakah data berada pada distribusi normal atau tidak dan uji homogenitas untuk melihat apakah data berjenis homogen atau heterogen. Dari perhitungan yang dilakukan, data nilai pretest ini berdistribusi normal dan homogen. Kemudian data nilai pretest dilakukan uji t dua pihak untuk mengetahui apakah terdapat perbedaan secara signifikan nilai rata-rata pretest antar kelas eksperimen dan kelas kontrol. Berdasarkan hasil penghitungan uji $\mathrm{t}$ dua pihak diperoleh nilai $t_{\text {hitung }}=1,895$ dan $t_{\text {tabel }} 1,940$ atau $t_{\text {hitung }}<t_{\text {tabel }}$. Berdasarkan kriteria pengujian, maka $\mathrm{H}_{0}$ diterima. Hal ini menunjukkan bahwa data pretest kelas eksprimen dan kelas kontrol tidak memiliki perbedaan rata-rata kemampuan awal pemahaman konsep matematis. Setelah siswa diberikan pretest untuk melihat kemampuan awal pemahaman konsep matematis yang dimiliki siswa, selanjutnya siswa diberikan perlakuan berupa pembelajaran matematika dengan model pembelajaran SSCS.

Selanjutnya, rata-rata nilai posttest kelas eksperimen lebih tinggi dibandingkan dengan kelas kontrol dengan perbedaan yang signifikan. Dari data tersebut, hasil penghitungan uji $\mathrm{t}$ dua pihak diperoleh nilai thitung $=3,757$ dan 
$t_{\text {tabel }} 1,940$ atau $t_{\text {hitung }}>t_{\text {tabel }}$. Hal ini menunjukkan bahwa data posttest kelas eksperimen dan kelas kontrol memiliki perbedaan peningkatan kemampuan pemahaman konsep matematis yang signifikan. Untuk melihat peningkatan nilai posttest yang lebih tinggi diantara kelas eksperimen dan kelas kontrol, maka dilakukan uji t satu pihak kanan. Berdasarkan hasil penghitungan uji t satu pihak diperoleh nilai $t_{\text {hitung }}=3,757$ dan $t_{\text {tabel }} 1,668$ atau $t_{\text {hitung }}>t_{\text {tabel }}$, menunjukkan bahwa skor rata-rata peningkatan kemampuan pemahaman konsep matematis siswa setelah pembelajaran pada kelas eksperimen lebih baik daripada kelas kontrol.

$N$-gain yang diperoleh kelas eksperimen lebih tinggi dibandingkan kelas kontrol. Berdasarkan hasil penghitungan uji t satu pihak diperoleh nilai $t_{\text {hitung }}=3,757$ dan $t_{\text {tabel }} 1,668$ atau $t_{\text {hitung }}>t_{\text {tabel, }}$ menunjukkan bahwa skor rata-rata peningkatan kemampuan pemahaman konsep matematis siswa seteleah pembelajaran pada kelas eksperimen lebih baik daripada kelas kontrol. Berdasarkan hasil pengolahan data penelitian yang telah dilakukan, peneliti menemukan bahwa kemampuan pemahaman konsep matematis siswa mengalami peningkatan yang signifikan kearah yang lebih baik setelah belajar menggunakan model pembelajaran SSCS. Sedangkan, secara lebih rinci dapat dilihat peningkatan rata-rata dari setiap indikator pada Tabel 2 .

Faktor yang mempengaruhi meningkatnya kemampuan pemahaman konsep matematis dengan menerapkan model pembelajaran SSCS adalah dalam pelaksanaannya model ini mengajak siswa untuk aktif dalam kegiatan diskusi maupun kegiatan individu dan mem-

Tabel 2. Rata-rata Peningkatan Kemampuan Pemahaman Konsep Matematis Per-Indikator

\begin{tabular}{|c|c|c|c|c|c|}
\hline Indikator & Kelas & Pretes & posttest & N-Gain & Klasifikasi \\
\hline \multirow{2}{*}{$\begin{array}{l}\text { Menyatakan ulang sebuah kon- } \\
\text { sep }\end{array}$} & Eksperimen & 68,5 & 97,5 & 0,32 & Sedang \\
\hline & Kontrol & 49,5 & 115 & 0,59 & Sedang \\
\hline \multirow{2}{*}{$\begin{array}{l}\text { Mengklasifikasikan objek me- } \\
\text { nurut sifat-sifat tertentu } \\
\text { sesuai dengan konsepnya }\end{array}$} & Eksperimen & 113,5 & 128 & 0,31 & Sedang \\
\hline & Kontrol & 83,5 & 123 & 0,52 & Sedang \\
\hline \multirow{2}{*}{$\begin{array}{l}\text { Memberikan contoh dan bukan } \\
\text { contoh dari suatu konsep }\end{array}$} & Eksperimen & 75,5 & 125,5 & 0,59 & Sedang \\
\hline & Kontrol & 72 & 123 & 0,58 & Sedang \\
\hline \multirow{2}{*}{$\begin{array}{l}\text { Menyajikan konsep dalam ber- } \\
\text { bagai bentuk representasi } \\
\text { matematis }\end{array}$} & Eksperimen & 51 & 129 & 0,72 & Tinggi \\
\hline & Kontrol & 51,5 & 109,5 & 0,53 & Sedang \\
\hline \multirow{2}{*}{$\begin{array}{l}\text { Mengembangkan syarat perlu } \\
\text { atau syarat cukup dari suatu } \\
\text { konsep }\end{array}$} & Eksperimen & 7,5 & 92,5 & 0,56 & Sedang \\
\hline & Kontrol & 12,5 & 68 & 0,38 & Sedang \\
\hline \multirow{2}{*}{$\begin{array}{l}\text { Menggunakan dan memanfaat- } \\
\text { kan serta memilih prosedur } \\
\text { atau operasi tertentu }\end{array}$} & Eksperimen & 44,7 & 126,7 & 0,71 & Tinggi \\
\hline & Kontrol & 27,3 & 72,3 & 0,34 & Sedang \\
\hline \multirow{2}{*}{$\begin{array}{l}\text { Mengaplikasikan konsep atau } \\
\text { algoritma dalam pemecahan } \\
\text { masalah }\end{array}$} & Eksperimen & 8,5 & 70 & 0,41 & Sedang \\
\hline & Kontrol & 5,5 & 30 & 0,16 & Rendah \\
\hline
\end{tabular}


Tabel 3. Statistika Deskriptif Data Nilai Pretest, Posttest, dan N-gain Disposisi Matematis

\begin{tabular}{lcccccc}
\hline \multicolumn{1}{c}{ Kategori } & \multicolumn{2}{c}{ Pretest } & \multicolumn{2}{c}{ Posttest } & \multicolumn{2}{c}{ N-gain } \\
& $\begin{array}{c}\text { Kelas } \\
\text { Eksperimen }\end{array}$ & $\begin{array}{c}\text { Kelas } \\
\text { Kontrol }\end{array}$ & $\begin{array}{c}\text { Kelas } \\
\text { Eksperimen }\end{array}$ & $\begin{array}{c}\text { Kelas } \\
\text { Kontrol }\end{array}$ & $\begin{array}{c}\text { Kelas } \\
\text { Eksperimen }\end{array}$ & $\begin{array}{c}\text { Kelas } \\
\text { Kontrol }\end{array}$ \\
\hline Banyak siswa & 40 & 40 & 40 & 40 & 40 & 40 \\
Data terbesar & 136 & 127 & 155 & 148 & 0,34 & 0,30 \\
Data terkecil & 71 & 67 & 102 & 86 & 0,05 & 0,09 \\
Rentang & 65 & 60 & 53 & 62 & 0,29 & 0,21 \\
Rata-rata & 109,5 & 102,73 & 125,70 & 121,28 & 0,181 & 0,207 \\
Simpangan baku & 15,66 & 16,18 & 12,29 & 14,84 & 0,074 & 0,056 \\
Varians & 245,13 & 261,64 & 150,93 & 220,10 & 0,005 & 0,003 \\
\hline
\end{tabular}

biasakan siswa untuk menyelesaikan persoalan matematika dengan cara dan langkah yang sistematis serta menekankan siswa untuk terlebih dahulu memahami permasalahan pada setiap fasenya sehingga akan membentuk pemahaman yang baik. Hal ini sejalan dengan teori Bruner yang menyatakan bahwa belajar matematika akan lebih berhasil jika proses pengajaran diarahkan kepada konsep-konsep dan strukturstruktur yang termuat dalam pokok bahasan yang diajarkan (Suherman, dkk, 2003:43). Dengan mengenal konsep dan struktur yang tercakup dalam bahan yang sedang diajarkan, siswa akan memahami materi yang harus dikuasainya.

Dari Tabel 3, dapat dilihat bahwa untuk rata-rata hasil skala awal kelas eksperimen lebih tinggi dibandingkan dengan kelas kontrol meskipun perbedaannya tidak terlalu signifikan. Selanjutnya dilakukan uji normalitas untuk melihat apakah data berada pada distribusi normal atau tidak dan uji homogenitas untuk melihat apakah data berjenis homogen atau heterogen. Dari perhitungan yang dilakukan, data nilai pretes ini berdistribusi normal dan homogen. Kemudian data skala awal dilakukan uji t dua pihak untuk mengetahui apakah terdapat perbedaan secara signifikan nilai rata- rata skala awal antar kelas eksperimen dan kelas kontrol. Berdasarkan hasil penghitungan uji t dua pihak diperoleh nilai $t_{\text {hitung }}=1,901$ dan $t_{\text {tabel }}=1,940$ atau $t_{\text {hitung }}<t_{\text {tabel }}$. Berdasarkan kriteria pengujian, maka $\mathrm{H}_{0}$ diterima. Hal ini menunjukkan bahwa data skala awal disposisi matematis kelas eksprimen dan kelas kontrol tidak memiliki perbedaan rata-rata kemampuan awal disposisi matematis. Setelah siswa diberikan skala awal untuk melihat kemampuan awal disposisi matematis yang dimiliki siswa, selanjutnya siswa diberikan perlakuan berupa pembelajaran matematika dengan model pembelajaran SSCS.

Rata-rata skala akhir disposisi matematis kelas eksperimen dan kelas kontrol sama-sama mengalami peningkatan, namun peningkatan yang lebih tinggi dialami oleh kelas kontrol. Dari data tersebut, hasil penghitungan uji $\mathrm{t}$ dua pihak diperoleh nilai $t_{\text {hitung }}=1,454$ dan $t_{\text {tabel }} 1,940$ atau $t_{\text {hitung }}<t_{\text {tabel. }}$. Hal ini menunjukkan bahwa tidak terdapat perbedaan peningkatan disposisi matematis antara kelas eksperimen dan kelas kontrol secara signifikan. Untuk melihat peningkatan skala akhir disposisi matematis yang lebih tinggi diantara kelas eksperimen dan kelas kontrol, 
maka dilakukan uji t satu pihak kanan. Berdasarkan hasil penghitungan uji t satu pihak diperoleh nilai $t_{\text {hitung }}=1,454$ dan $t_{\text {tabel }} 1,668$ atau $t_{\text {hitung }}<t_{\text {tabel, }}$ menunjukkan bahwa skor rata-rata peningkatan disposisi matematis siswa setelah belajar dengan menggunakan model SSCS pada kelas eksperimen lebih rendah atau sama dengan kelas kontrol.

Selanjutnya, terlihat bahwa ratarata $\mathrm{N}$-gain disposisi matematis siswa kelas eksperimen lebih rendah dari kelas kontrol. Berdasarkan hasil penghitungan uji $\mathrm{t}$ satu pihak diperoleh $\mathrm{t}_{\text {hitung }}=-2,143$ dan $t_{\text {tabel }} 1,668$ atau $t_{\text {hitung }}>t_{\text {tabel }}$, menunjukkan bahwa skor rata-rata peningkatan disposisi matematis siswa setelah pembelajaran pada kelas eksperimen lebih rendah atau sama dengan kelas kontrol Berdasarkan hasil pengolahan data penelitian yang telah dilakukan, peneliti menemukan bahwa disposisi matematis siswa setelah belajar menggunakan model pembelajaran SSCS mengalami peningkatan yang tidak signifikan dibandingkan dengan kelas kontrol. Secara lebih rinci peningkatan rata-rata dari setiap indikator terdapat pada Tabel 4.

Tabel 4. Rata-rata Peningkatan Disposisi Matematis Per-Aspek

\begin{tabular}{lcc}
\hline \multirow{2}{*}{ Aspek } & \multicolumn{2}{c}{$N$-Gain } \\
\cline { 2 - 3 } & $\begin{array}{c}\text { Kelas } \\
\text { Eksperimen }\end{array}$ & $\begin{array}{c}\text { Kelas } \\
\text { Kontrol }\end{array}$ \\
\hline $\begin{array}{c}\text { Ketertarikan } \\
\text { Terhadap }\end{array}$ & 0,23 & 0,17 \\
$\quad$ Matematika & & \\
Kepercayaan Diri & 0,20 & 0,18 \\
Kegigihan dan & 0,20 & 0,24 \\
$\quad$ Ketekunan & & \\
Fleksibelitas & 0,10 & 0,18 \\
Metakognisi & 0,15 & 0,19 \\
\hline
\end{tabular}

Berdasarkan Tabel 4 kita dapat menyimpulkan peningkatan disposisi matematis dari setiap aspek melalui $N$ gainnya yang didapat dari kelas eksperimen dan kelas kontrol. Dari peningkatan rata-rata setiap aspek, dapat kita simpulkan bahwa peningkatan ratarata disposisi matematis kelas kontrol lebih baik dari kelas eksperimen. Penyebab lebih rendah nya peningkatan disposisi matematis kelas eksperimen dibanding kelas kontrol adalah sulitnya siswa untuk beradaptasi dengan model pembelajaran yang baru siswa kenal, dalam hal ini adalah model pembelajaran SSCS. Dan karakter siswa pun sangat mempengaruhi hasil penelitian, misalnya pada kelas eksperimen siswa cenderung ingin bekerja sendiri disaat diberikan tugas secara berkelompok dan sebagian besar dari mereka kurang tekun dalam mengerjakan sesuatu. Karakter siswa yang kurang bersosialisasi dan mudah untuk merasa tidak mampu menjadi salah satu faktor yang mempengaruhi karena meskipun sudah disiapkan reward, siswa tetap cenderung pada karakternya dan sulit menerima aturan baru yang dibuat guru dalam pembelajaran dengan menggunakan model SSCS. Berbeda dengan siswa pada kelas kontrol, yang mudah untuk bekerja secara kelompok, berdiskusi dengan baik, serta tidak mudah merasa putus asa saat diberikan soal matematika. Hal ini sesuai dengan teori belajar Edward L. Thorndike (Suherman, 2003: 28) yang mengemukakan beberapa hukum belajar yang dikenal dengan Law of Effect. Menurut hukum ini belajar akan lebih berhasil bila respon siswa terhadap suatu stimulus segera diikuti 
dengan rasa senang atau kepuasan. Teori ini menyatakan bahwa pada hakikatnya belajar merupakan proses pembentukan hubungan stimulus dan respon. Kemungkinan siswa pada kelas eksperimen merasa kurang nyaman karena belum terbiasa nya pembelajaran matematika dengan menggunakan model pembelajaran SSCS, sehingga mengakibatkan siswa tidak memiliki peningkatan yang tinggi terhadap disposisi matematisnya.

\section{Pembelajaran Matematika dengan Model Pembelajaran SSCS}

Setelah melakukan proses pembelajaran matematika sebanyak lima pertemuan dengan menggunakan model pembelajaran SSCS, peneliti menemukan bahwa model pembelajaran ini dapat meningkatkan pemahaman konsep pada pembelajaran matematika karena ratarata $\mathrm{N}$-gain kelas eksperimen yang menggunakan model SSCS lebih baik daripada kelas kontrol. Model pembelajaran SSCS ini juga efektif dalam menciptakan suasana belajar yang lebih baik. Model pembelajaran ini menuntut siswa untuk lebih mandiri, percaya diri, mudah bersosialisasi dan mengasah kemampuan pemahaman konsep yang dimiliki. Karena pada setiap fase dalam model pembelajaran SSCS dapat membentuk sikap positif pada siswa.

Pada fase search, siswa akan dituntut untuk mandiri, artinya siswa harus memahami soal-soal yang diberikan oleh peneliti kemudian mencari informasi-informasi yang berkaitan dengan soal tersebut. Pada fase ini peneliti hanya bertugas sebagai pendorong dan pembimbing agar siswa dapat menemukan informasi-informasi yang tepat terkait permasalahan yang ada. Adapun kendala dalam fase ini adalah kurang nya pengetahuan awal siswa dan melupakan materi-materi yang telah dipelajari sebelumnya. Hal tersebut membuat siswa sulit memahami dan mencari informasi yang dibutuhkan pada permasalahan yang diberikan.

Pada fase solve, siswa diharuskan memikirkan dan memilih penyelesaian dari soal yang diberikan secara tepat. Dalam fase ini peneliti bertugas sebagai pembimbing sekaligus pengawas agar siswa memilih penyelesaian soal secara tepat. Kendala dalam fase solve ini adalah kurangnya kerjasama antar siswa yang membuat mereka bingung memilih penyelesaian yang akan dipilih karena beberapa pendapat yang diberikan dari anggota kelompok lainnya.

Selanjutnya pada fase create, siswa harus menuliskan secara rinci dan jelas penyelesaian soal yang dipilih pada fase solve. Pada fase ini peneliti hanya memantau dan membimbing siswa dalam cara menuliskan penyelesaian soal yang telah dipilih. Kendala dalam fase ini adalah kurangnya pengetahuan siswa dalam menuliskan lambang, rumus atau simbol dalam matematika. Kemudian pada fase terakhir, yaitu fase share, siswa harus memberanikan diri untuk menjelaskan hasil kerja mereka di depan kelas. Dalam fase ini, peneliti berperan sebagai fasilitator untuk memilih perwakilan dari setiap kelompok. Kendala dalam fase ini adalah waktu yang tidak cukup karena terpakai pada fase yang lain. Pada fase ini juga sebagian siswa tidak mau untuk mempresentasikan hasil kerja nya. Dari semua fase ini setiap siswa dituntut untuk dapat memahami 
setiap permasalahan atau soal yang diberikan kemudian harus memahami penyelesaian yang telah dipilih, dan untuk menjelaskan didepan kelas secara otomatis siswa wajib untuk memahami konsep, rumus, dan soal yang diberikan. Hal ini sesuai dengan teori konstruktivisme Piaget yang menjelaskan bahwa proses dibangunnya sebuah pengetahuan dari stimulus baru dilakukan dengan dua cara, yaitu asimilasi dan akomodasi. Asimilasi adalah proses pengintegrasian informasi baru ke dalam struktur pikiran. Sedangkan akomodasi adalah proses membentuk atau memodifikasi struktur pikiran karena adanya informasi baru yang tidak dapat diasimilasi. Dengan demikian dalam proses asimilasi, seseorang hanya memperoleh pengetahuan baru tetapi tidak menambahkan kualitas pengetahuan, sedangkan pada proses akomodasi kualitas pengetahuan seseorang akan bertambah, juga didukung oleh teori Vygotsky tentang scaffolding yaitu memberikan sejumlah besar bantuan kepada seorang anak selama tahap-tahap awal pembelajaran dan kemudian mengurangi bantuan tersebut dan memberikan kesempatan kepada anak tersebut mengambil alih tanggung jawab yang semakin besar segera setelah mampu mengerjakan sendiri. Bantuan yang diberikan guru dapat berupa petunjuk, peringatan, dorongan, menguraikan masalah ke dalam bentuk lain yang memungkinkan siswa dapat mandiri (Mardiyan, 2013).

Teori behaviorisme Pavlov mengatakan bahwa belajar diartikan sebagai kondisi yang menghasilkan perubahan perilaku yang timbul secara terus menerus. Oleh karena itu pembelajaran yang baik haruslah mampu mengubah perilaku manusia ke arah yang lebih baik. Salah satu perilaku baik dalam matematika yang dapat dipengaruhi adalah disposisi matematis. Model pembelajaran SSCS ini dapat mempengaruhi disposisi matematis siswa, meskipun tidak meningkatkan secara signifikan namun terlihat bahwa disposisi siswa pada kelas eksperimen menjadi lebih baik dari sebelumnya. Setidaknya mereka akan merasa sedikit percaya diri, karena dalam pembelajaran ini siswa akan "dipaksa" untuk maju kedepan kelas dan dipilih secara acak. Mereka juga tidak hanya harus percaya diri, akan tetapi harus mau bekerja secara tim (kelompok) dan menghargai segala pendapat atau perbedaan yang ada didalam kelompok mereka. Pada model pembelajaran ini, siswa akan terus melatih beberapa aspek disposisi matematis seperti ketertarikan terhadap matematika, percaya diri, flesibelitas, tekun dan gigih serta kemampuan metakognitif.

Dengan demikian, dari semua hasil pengolahan data penelitian beserta pengamatan peneliti selama proses pembelajaran, model pembelajaran SSCS ini sangat membantu siswa untuk bisa belajar secara serius, terstruktur dan lebih mandiri dalam belajar matematika.

\section{PENUTUP}

Berdasarkan hasil analisis dan uji hipotesis yang telah dilakukan, maka diperoleh kesimpulan sebagai berikut. Peningkatan kemampuan pemahaman konsep matematis siswa yang belajar matematika menggunakan model pembelajaran SSCS memiliki peningkatan 
yang signifikan. Hal ini ditunjukkan pada hasil uji satu pihak (pihak kanan) terhadap nilai posttest dimana nilai thitung $(3,757) \geq t_{\text {tabel }}(1,668)$ dan diperkuat oleh uji hipotesis satu pihak terhadap $\mathrm{N}$-gain dimana $t_{\text {hitung }}(3,750) \geq t_{\text {tabel }}(1,668)$ yang menyatakan bahwa peningkatan kemampuan pemahaman konsep matematis siswa yang belajar menggunakan model pembelajaran SSCS lebih baik daripada siswa yang belajar matematika dengan model ekspositori.

Peningkatan disposisi matematis siswa yang belajar matematika menggunakan model pembelajaran SSCS memiliki peningkatan yang tidak signifikan. Hal ini terlihat dari hasil uji satu pihak terhadap skala akhir dimana $t_{\text {hitung }}(1,454)<t_{\text {tabel }}(1,940)$ yang menyatakan bahwa peningkatan disposisi matematis yang belajar menggunakan model pembelajaran SSCS lebih rendah atau sama dengan siswa yang belajar matematika dengan model ekspositori.

Berdasarkan pengalaman penelitian, hasil pembahasan dan kesimpulan diatas, maka dapat diberikan saran-saran sebagai berikut. Bagi siswa, sebelum pembelajaran dimulai, sebaiknya siswa sudah dibentuk secara kelompok dengan penentuan guru, agar pada saat pembelajaran akan dimulai siswa dapat langsung belajar secara kondusif. Dan siswa harus mengikuti semua aturan dalam proses pembelajaran. Bagi guru, model pembelajaran SSCS dapat dijadikan alternatif pada pembelajaran matematika sebagai variasi pembelajaran. Sebelum pembelajaran dimulai, guru hendaknya mengenalkan terlebih dahulu cara atau langkah-langkah pembelajaran dengan menggunakan model SSCS.
Selain itu selama proses pembelajaran berlangsung hendaknya memperhatikan waktu. Bagi peneliti lain, dalam penelitian ini masih banyak kekurangan terutama pada terbatasnya referensi untuk materi ajar. Diharapkan ada pihak lain yang meneruskan penelitian ini dengan menambah referensi materi ajar agar mendapatkan perangkat pembelajaran yang lebih baik untuk meningkatkan kualitas pembelajaran.

\section{DAFTAR PUSTAKA}

Anwar, R. (2013). Desain Didaktis Interaktif Problem Solving Matematis pada Pokok Bahasan Kesebangunan. Skripsi UNTIRTA Serang: Tidak Diterbitkan.

Deli, M (2015). Penerapan Model Pembelajaran Search Solve Share (SSCS) Untuk Meningkatkan Motivasi Belajar Matematika Siswa Kelas VII-2 SMP Negeri 13 Pekanbaru [Online]. Tersedia di: http://ejournal.unri.ac.id/index.ph $\mathrm{p} / \mathrm{JPFKIP} /$ article/view/2725 [Diakses pada tanggal 3 Oktober 2016]

Harja, M. (2012). Pemahaman Konsep Matematis [Online]. Tersedia di: http://mediaharja.blogspot.co.id/2 012/05/pemahaman-konsepmatematis.html [Diakses pada tanggal 9 Oktober 2016]

Irwan. (2011). Pengaruh Pendekatan Problem Posing Model Search, Solve, Create And Share (SSCS) Dalam Upaya Meningkatkan Kemampuan Penalaran Matematis Mahasiswa Matematika [Online].Tersedia di: http://jurnal.upi.edu/file/irwan.pdf [Diakses pada tanggal 3 Oktober 2016] 
110 | Lilis Haniyyah, Khairida Iskandar, Isna Rafianti-Pembelajaran Search, Solve, Create and Share (SSCS) untuk ....

Kilpatrick, J., Swafford, J., \& Findell, B. (Eds.). 2001. Adding it up: Helping children learn mathematics. Washington, DC: National Academy Press.

Mardiyan, R. (2013). Metode Pembelajaran Scaffolding [Online]. Tersedia di: https://rirymardiyan04.wordpress. com/2013/04/27/86/ [Diakses pada tanggal 1 Juni 2017]

Marogi, A. (2016). Disposisi Matematika [Online]. Tersedia di: http://tamamilmi.blogspot.co.id/2 016/07/disposisi-matematika.html [Diakses pada tanggal 9 Desember 2016]

NCTM. (1989). Curriculum and Evaluation Standars for School Mathematics. Evaluation Standard: $\quad$ Standard 10Mathematical Disposition, Reston, VA: National Council of Teachers of Mathematics [Online]. Tersedia di:

http://webapp1.dlib.indiana.edu/vi rtual_disk_library/index.cgi/4273 355/FID1736/curric/enc2280/280 dtoc1.htm [Diakses pada tanggal 2 Februari2017]

Rizki, T.R. (2015). Penerapan Pendekatan Scientific Melalui Pembelajaran Problem Solving Terhadap Peningkatan
Pemahaman Konsep Matematis Siswa SMP. Skripsi UNTIRTA Serang: Tidak Diterbitkan.

Ruseffendi, E. T. (2010). Dasar-Dasar Penelitian Pendidikan dan Bidang Non-Eksakta Lainnya. Bandung: Tarsito.

Sanjaya, W. (2009). Strategi Pembelajaran Berorientasi Standar Proses Pendidikan. Jakarta: Kencana.

Suherman, E, dkk. (2003). Strategi Pembelajaran Matematika Kontemporer. Bandung: UPI.

Trisniawati. (2013). Disposisi Matematis. [Online]. Tersedia di: http://trisniawati87.blogspot.co.id/ 2013/05/disposisimatematis_12.html [Diakses pada tanggal 9 Desember 2016]

Wardhani, S. (2008). Analisis SI dan SKL Mata Pelajaran Matematika SMP/MTs untuk Optimalisasi Tujuan Mata Palajaran Matematika.

Yogyakarta:PPPPTKM. Tersedia di:

http://p4tkmatematika.org/file/PR ODUK/PAKET\%20FASILITASI/ SMP/Analisis\%20SI\%20dan $\% 20$ SKL\%20Matematika\%20SMP.pd f [Diakses pada tanggal 9 Juni 2017] 